\title{
Does Value Outperform Growth In A Downturn?
}

\author{
T.G.Saji ${ }^{1}$ \\ ${ }^{I}$ (Commerce and management studies, Government college, Thrissur, India)
}

\begin{abstract}
What stocks, value or growth, one should own during the rough patch of a recession? Both academics and practitioners are often seeking answer to this question. This paper aims to provide empirical evidence in Indian context on the relative performance of value strategy using Price Earning $(P / E)$ ratio during the period of market downturns. The methodology used is based on the implications of the theory of financial markets and the methodology of fundamental analysis. By using a set of explanatory variables identified from Discounted Cash Flow (DCF) model - earnings growth, dividend payout and market risk coefficient - the study estimated a theoretical benchmark of P/E under a Multiple Regression framework against which observed P/E ratios of stocks from five selected sectors were compared. The empirical results of the study corroborated the implication of value strategy in wealth management during crisis times.
\end{abstract}

Keywords- earnings growth, market risk, P/E ratio, payout, Value strategy

\section{Introduction}

Financial research and literature abounds with valuation models which the stock market analysts use to uncover mispriced securities. These models are mainly used by the fundamental analysts, who use information concerning the current and prospective profitability of a company to assess its fair market value or economic worth thereby to identify underpriced and overpriced stocks. Most of these models are based on the present value theory which states that the real value or intrinsic value of a stock is just equal to the present value of all cash inflows that a shareholder may expect to receive in future. Magnitude of cash flows accruing from investments is uneven in nature and is varying in accordance with the alternate occurrence of different phases of economic cycles. One important implication of any stock valuation model is that (holding all else equal) risk of stocks (variability of cash flows) bears direct relationship with its Price Earning multiple or ratio (hereafter P/E ratio or $\mathrm{P} / \mathrm{E}$ multiple). So valuation model based on $\mathrm{P} / \mathrm{E}$ ratio is the most versatile fundamental yardstick for practitioners as well as academicians alike in evaluation of the level of market prices in general and the price of individual stocks in particular.

The crisis affected year of 2008 was not promising for most of the investment vehicles in India. Among the investment asset class equity was the worst performing asset [1]. When the broad based index "SENSEX" fell from its closing peak of 20,873 on January 8, 2008, to below 10,000 by October 17, 2008, the wealth position of the investors in India almost halved. Most of the scrips traded in the market have lost their value due to the contagion spread by the global financial tsunami. Fundamentalists might take it as an opportunity for investment under the assumption that stocks become underpriced during the times of crisis but eventually it makes huge profits for them during its subsequent recovery stage [2]. This paper intends to inform practitioners how well they can use $\mathrm{P} / \mathrm{E}$ ratio as a value strategy to identify mispriced securities during downturns.

The remainder of this paper proceeds as follows: the next section presents the theory and empirical literature on P/E ratios; Section 3 describes the methodology; Section 4 reports empirical findings, followed by concluding remarks in Section 5.

\section{Price Earnings Ratio: Theory And Empirical Literature}

The ratio of market value of common stock to reported net income is a widely used guide in the financial decision making of investors, businessmen and regulatory authorities [3]. A large number of investors often take low values for P/E ratio as a margin of safety or sign that a particular stock is a bargain. But rarely do they consider higher values for these indicators as an index of investor confidence and optimism about the growth prospects of the firm and its investments. The investment strategies pursued in the former case are known as Value strategies and Growth strategies for latter case. Value strategists suggest that an investor should choose the stocks with low ratio of market price share to earnings per share. These stocks are called value stocks because they have a low price relative to its earnings, already undervalued in the market and have a chance to increase its fair value or true worth. In contrast the growth strategists force the investors to choose growth stocks - stocks with high Price Earnings ratio suggesting that the firm will experience rapid growth to justify the prices at which its stocks sell.

Value investing is an investment theory that derives from the ideas of Benjamin Graham and David Dodd formed in their text Security Analysis [4].This extensive development of this approach found during 70's. Since 
then it has been practiced by many successful investors including Warrant Buffet, the most thriving student of Graham. On going through the available literature on the relative efficacy of one investment strategy over the other in terms of return, there seems to be a wide consensus among the academicians and practitioners alike on the argument of value strategies outperform growth strategies in many of the countries. P/E ratio can be high because of anticipated long-run earnings growth, but a firm with anticipated long-run earnings growth can have a low trailing P/E because current earnings are temporarily high[5]. Later several economic research and financial analysts have published studies which advocate selection of stocks with low Price Earnings ratio. Some of the studies of this kind are [6], [7], [8], [9], [10] and [11]. Higher P/E ratios are usually followed by lower stock price growth during the following decade [12]. Investors buy future earnings, so should pay less for current earnings if those earnings cannot be sustained in the future [13]. But many other studies have concluded with findings which seem to be more contentious nature. The most likely explanation of the evident persistence in $\mathrm{P} / \mathrm{E}$ ratio is not growth or risk, but difference in accounting method [14]. Analysts' errors have an asymmetrical impact on high and Low P/E stocks [15].

The financial markets usually anticipate recessions, and thus the first negatively affected. However, some of the financial market turmoil are being triggered without any rational causes and are being driven just by herd behavior of market players. In those times higher P/E ratio predicts not the future growth in stock prices, but the future falls and they could act as an indicator of the coming bear market[16]. This study incorporates in its methodology all these aspects of fundamental theory of financial market.

\subsection{Sample frame and Data}

\section{Data and methodology}

For the purpose of the study five sectors viz. Banking, Information Technology (IT), Reallty and Infra, Automobiles and Pharmaceuticals were identified. When the first two sectors represent growth industry group, third and fourth give proxy for cyclical industry and lastly Pharmaceutical is a true approximation for defensive category. From each sector four well performed companies during the period were selected. Annual reports of the companies provided required financial data and data on stock prices were taken from NSE website. All the financial data were related to the financial years from 2004-05 to 2008-09 and daily share price data covering the period from $1^{\text {st }}$ April 2008 to $31^{\text {st }}$ December 2009.

\subsection{Methodology}

\subsection{1. $\mathrm{P} / \mathrm{E}$ determinants}

Theories of security analysis state that the P/E multiple is the best proxy for the financial strength of a scrip. This is because there is causal relationship between financial fundamentals of a firm and its PE multiples. The fundamentals that determine multiples were extracted by using discounted cash flow model -the dividend discount model with constant growth of Gordon [17]. This model is based on the assumption that a part of company earnings is retained (b) and the remaining part is paid out as dividend (p).

$\mathrm{P} / \mathrm{E}$ ratio for a stable growth firm from the stable growth dividend discount model is derived at first in a mathematical way.

$$
\begin{gathered}
: \mathrm{P}_{0}=\frac{\mathrm{D}_{1}}{\mathrm{k}_{\mathrm{e}}-\mathrm{g}_{\mathrm{n}}} \\
\mathrm{P}_{0}=\frac{\mathrm{E}_{1} * \mathrm{P}}{\mathrm{k}_{\mathrm{e}}-\mathrm{g}_{\mathrm{n}}} \\
\frac{\mathrm{P}_{0}}{\mathrm{E}_{1}}=\frac{\mathrm{p}}{\mathrm{k}_{\mathrm{e}}-\mathrm{g}_{\mathrm{n}}}
\end{gathered}
$$

Where, $\mathrm{E}_{1}=$ Expected earnings in time period $(\mathrm{t}+1)$

$$
\begin{aligned}
& \mathrm{g}_{\mathrm{n}}=\text { Growth rate in the first } \mathrm{n} \text { years } \\
& \mathrm{k}_{\mathrm{e}}=\text { Cost of equity or expected rate of return } \\
& \mathrm{P}_{0}=\text { current price of the share } \\
& \mathrm{P}=\text { dividend payout } \\
& \mathrm{D}_{1}=\mathrm{P} * \mathrm{E}_{1} \text { (dividend defined in time period } \mathrm{t}+1 \text { ) }
\end{aligned}
$$

Here the model assumes that $\mathrm{P}_{0}$ tends to $\mathrm{V}_{0}$ (intrinsic value) in the long run. 
$: \mathrm{V}_{0}=(\mathrm{P} / \mathrm{E})_{\mathrm{N}} * \mathrm{E}_{1}$

$(\mathrm{P} / \mathrm{E})_{\mathrm{N}}$ equal to $\left(\mathrm{P}_{0} / \mathrm{E}_{1}\right)$

It is evident from the aforesaid models that $\mathrm{P} / \mathrm{E}$ ratio of a firm is determined by its earnings, expected rate of return (indirectly indicating riskiness) and dividend payout. So one can assume the following relationship of P/E ratio of a growth firm with these three determinant variables: (a) with payout ratio: the P/E ratio increases as the payout ratio increases. (b) with riskiness (through the discount rate $\mathrm{k}_{\mathrm{e}}$ ): the P/E ratio becomes lower as risk increases.(c) with expected growth rate in earnings: the $\mathrm{P} / \mathrm{E}$ increases as the growth rate increases.

\subsubsection{Normal or Expected P/E ratio}

The determination of the current $\mathrm{P} / \mathrm{E}$ on a stock must be followed by a standard of comparison or an appropriate benchmark. This bench mark rate is usually termed as Normal P/E ratio. With this benchmark the security analyst compares the actual $\mathrm{P} / \mathrm{E}$ ratio of each firm that he has considered for the purpose of his investment. Here a theoretical benchmark of $\mathrm{P} / \mathrm{E}$ ratio (hereafter we call expected $\mathrm{P} / \mathrm{E}$ ratio) is estimated by performing regressions of actual P/Es against the relevant determinant variables. Extensive empirical work has been done on the relation of past growth of earnings, riskiness and dividends to price and P/E multiples [18]. For giving proxy to riskiness, instead of total risk, market risk is considered in the studies like [19]. Similar methodology has been observed to estimate the P/E ratio by later studies [20] and [21]. This study is also followed the same methodology to estimate P/E under the assumption of complete diversification of company risk through rational sample selection.

The causal relationship between the P/E and its determinants identified from the discount model is captured with a classical linear regression model expressed in the form of equation (3):

$$
\begin{aligned}
Y_{i}=\alpha & +\beta_{1} x_{1}+\beta_{2} x_{2}+\beta_{3} x_{3}+u_{i} \\
\mathrm{y}_{\mathrm{i}} & =\quad \text { Expected } \mathrm{P} / \mathrm{E} \text { multiple. } \\
\mathrm{x}_{1} & =\quad \text { Earnings growth } \\
\mathrm{x}_{2} & =\quad \text { Dividend payout } \\
\mathrm{x}_{3} & =\quad \text { Beta or market risk factor } \\
u_{i} & =\text { Error term with zero mean and constant standard deviation. }
\end{aligned}
$$

For the purposes of examining such relationship, one should use an average of earnings of "not less than five years [4]. So geometric mean of five years' earnings growth and median dividend payout of the companies during the same period were given as proxies for earnings growth and dividend payout respectively. The betas were estimated with the help of the following simple linear regression equation (4):

$$
\begin{aligned}
R_{i}= & \alpha+\beta_{i} R_{m}+u_{i} \\
& R_{i}=\text { Return from individual scrip. } \\
& \alpha=\text { Intercept of a straight line or alpha coefficient. } \\
& \beta_{i}=\text { Beta coefficient of } \mathrm{i}^{\text {th }} \text { scrip. } \\
& R_{m}=\text { Return on benchmark index. } \\
& u_{i}=\text { Error term with zero mean and constant standard deviation. }
\end{aligned}
$$

\subsubsection{Comparing Actual and Normal P/E ratios}

The investors should then compare the P/E based on the regression estimate with the actual PE ratio to make valuation judgments. The results of this comparison are used to reach any one of three possible conclusions:

- If actual $\mathrm{P} / \mathrm{E}$ is larger than the expected $\mathrm{P} / \mathrm{E}$, the stock is overpriced.

- If actual $\mathrm{P} / \mathrm{E}$ is smaller than the expected $\mathrm{P} / \mathrm{E}$, the stock is underpriced; it could be purchased with a reasonable expectation that its price will rise.

- If actual $\mathrm{P} / \mathrm{E}$ equals the expected $\mathrm{P} / \mathrm{E}$, the stock is correctly priced; no significant price changes are likely to occur.

Investors and security analysts who believe in fundamental approach to valuation follow this strategy. The outcome expected here is that overpriced stocks have their own intrinsic values and $\mathrm{P} / \mathrm{E}$ driven down to appropriate levels by selling pressure, underpriced stocks find its real worth and P/E ratio bid up, and correctly priced stocks experience non consistent buying or selling pressures to cause their prices to change. Market pressures tend to keep stock prices near the intrinsic values reached by the fundamental analyst's consensus. 
Does Value Outperform Growth In A Downturn?

4.1. Selected fundamentals of companies in 2008-09

\section{Results And Discussions}

Table 1: Selected fundamentals of companies (2008-09)

\begin{tabular}{|c|c|c|c|c|c|c|c|}
\hline Sector & Company & EPS & $\begin{array}{c}\text { Dividen } \\
\text { d payout }\end{array}$ & Price & $\begin{array}{c}\mathbf{P} / \mathbf{E} \\
\text { ratio } \\
\end{array}$ & $\begin{array}{c}\text { EPS growth } \\
(\%)\end{array}$ & Beta \\
\hline \multirow{4}{*}{ Banking } & Bank of India & 57.26 & 16.34 & 219.4 & 3.83 & 49.66 & 1.09 \\
\hline & SBI & 143.67 & 22.90 & 1067.1 & 7.43 & 34.83 & 1.10 \\
\hline & Union Bank of India & 34.18 & 17.11 & 146.85 & 4.30 & 24.47 & 1.01 \\
\hline & PNB & 98.03 & 23.86 & 411.45 & 4.20 & 50.86 & 0.96 \\
\hline \multirow{4}{*}{$\begin{array}{l}\text { Realty and } \\
\text { Infra }\end{array}$} & Unitech & 4.56 & 3.23 & 35.20 & 7.72 & -28.19 & 1.68 \\
\hline & JP Associates & 7.58 & 15.91 & 84.10 & 11.09 & 45.77 & 1.85 \\
\hline & DLF & 9.08 & 23.79 & 167.30 & 18.43 & -39.87 & 1.54 \\
\hline & Rel Infra & 50.38 & 16.19 & 515.55 & 10.23 & 9.43 & 1.83 \\
\hline \multirow{4}{*}{$\begin{array}{c}\text { Automobile } \\
\text { s }\end{array}$} & Hero Honda & 64.19 & 36.45 & 1065.73 & 16.60 & 32.43 & 0.36 \\
\hline & Maruti & 42.18 & 9.71 & 779.85 & 18.49 & -29.59 & 0.72 \\
\hline & Mahindra \& Mahindra & 30.60 & 37.29 & 380.17 & 12.42 & -33.69 & 0.98 \\
\hline & Tata motors & 19.48 & 34.52 & 180.30 & 9.26 & -62.99 & 1.15 \\
\hline \multirow{4}{*}{$\begin{array}{c}\text { Pharmasuet } \\
\text { icals }\end{array}$} & Cipla & 9.99 & 23.41 & 221.02 & 22.12 & 10.75 & 0.51 \\
\hline & Lupin & 50.35 & 29.04 & 685.00 & 13.60 & -8.20 & 0.50 \\
\hline & Sun pharma & 61.09 & 26.33 & 1106.27 & 18.11 & 24.78 & 0.28 \\
\hline & Dr. Reddy's & 33.29 & 21.94 & 483.31 & 14.52 & 17.80 & 0.38 \\
\hline \multirow{4}{*}{ Software } & TCS & 47.92 & 34.2 & 538.55 & 11.24 & 4.02 & 0.91 \\
\hline & Wipro & 20.30 & 23.05 & 245.46 & 12.09 & -3.15 & 0.99 \\
\hline & Infosys Technologies & 101.58 & 27.03 & 1323.27 & 13.03 & 29.98 & 0.72 \\
\hline & HCL Technologies & 14.88 & 55.08 & 102.05 & 6.86 & 26.96 & 1.01 \\
\hline
\end{tabular}

From Table 1 we can observe inter sectoral as well as intra sectoral difference in financial fundamentals of the corporate. In absolute terms of EPS, all sectors except realty and infra did well, but only the banking companies could maintain parity among them in terms of their growth in earnings. However, almost all companies declared dividend at relatively attractive rate. But the rate of earnings distributed by companies like Unitech and Maruti were marginal only. When realty stocks proved to be the most sensitive to market changes (more or less double), all the Pharma scrips justified its name of 'defensive class stocks.' When automobile sector made mixed reactions to the market conditions, banking and Information Technology made momentum at least in par with the general market movement. P/E ratios vary across industries and across firms because of differences in fundamentals.

\subsection{Correlation analysis}

The regression methodology is a convenient way of compressing large amounts of data into one equation capturing the relationship between $\mathrm{P} / \mathrm{E}$ ratios and financial fundamentals. But for the reliable results the independent variables (here the financial fundamentals) should be independent of each other. If it is not so, there is said to be the problem of multi - collinearity which makes the coefficients of the regressions unreliable and may explain the 'wrong' signs on the coefficients and the large changes in these coefficients from period to 
period. But in our model all the three independent variables are independent of each other (Table 2) signaling the reliability of the model in valuation of stocks. However, the basic relationship between P/E ratios and financial variables itself might not be stable, and if it shifts from year to year, the predictions from the regression equation may not be reliable for extended periods.

Table 2:Correlations between variables selected for the study

\begin{tabular}{|c|l|c|c|c|c|}
\hline & P/E ratio & $\begin{array}{c}\text { Earnings } \\
\text { growth }\end{array}$ & $\begin{array}{c}\text { Dividend } \\
\text { payout }\end{array}$ & Beta \\
\hline \multirow{4}{*}{$\begin{array}{c}\text { Pearson } \\
\text { Correlation }\end{array}$} & P/E ratio & 1.00 & -.308 & .013 & -.419 \\
\cline { 2 - 6 } & $\begin{array}{l}\text { Earnings } \\
\text { growth }\end{array}$ & -.308 & 1.000 & .022 & -.190 \\
\cline { 2 - 6 } & Dividend payout & .013 & .022 & 1.00 & -.341 \\
\cline { 2 - 6 } & Beta & -.419 & -.190 & -.341 & 1.00 \\
\hline \multirow{5}{*}{ Sig. (1-tailed) } & P/E ratio &. & $* * .100$ & .479 & $* .037$ \\
\cline { 2 - 6 } & Earnings growth & $* * .100$ &. & .464 & .218 \\
\cline { 2 - 6 } & Dividend payout & .479 & .464 &. & .122 \\
\cline { 2 - 6 } & Beta & $* .037$ & .218 & .122 &. \\
\hline
\end{tabular}

**significant at 10 percent level, * significant at 5 percent level

\subsection{Estimating Expected P/E ratio}

Table 3 displays the results of linear regression that included beta, earnings growth and dividend payout as independent variables. It can be easily read from the results that the expected sign of relationship of P/E with all the three independent variables found negative during the year 2008-09. When the relationship between P/E multiple with earnings growth and also with market risk coefficients found significant at 10 percent and 5 percent level of significance respectively, we could not observe significance at any level with regard to the dependence made by the $\mathrm{P} / \mathrm{E}$ multiple of the stocks on the fraction of its earnings distributed among the shareholders. From this we can infer that the investors are totally indifferent towards the dividend policy of the companies. Market value of stocks in India during the recession is much influenced by the rate of earnings of the companies and is independent of their dividend policy. So the results observed through this study are consistent with the findings of [19] except that of the relation between P/E and earnings growth.

Table 3 : Impact of financial fundamentals on P/E multiple

\begin{tabular}{|c|c|c|c|c|c|}
\hline \multirow[b]{2}{*}{ Model } & \multicolumn{2}{|c|}{ Unstandardized Coefficients } & \multirow{2}{*}{$\begin{array}{c}\begin{array}{c}\text { Standardized } \\
\text { Coefficients }\end{array} \\
\text { Beta }\end{array}$} & \multirow[b]{2}{*}{$\mathrm{t}$} & \multirow[b]{2}{*}{ Sig. } \\
\hline & & Std. Error & & & \\
\hline (Constant) & 20.504 & 4.360 & & 4.703 & $.000 *$ \\
\hline $\begin{array}{l}\text { Earnings } \\
\text { growth }\end{array}$ & -.066 & .034 & -.410 & -1.940 & $071 * *$ \\
\hline $\begin{array}{l}\text { Dividend } \\
\text { payout }\end{array}$ & -.077 & .102 & -.167 & -.757 & .461 \\
\hline Beta factor & -6.335 & 2.567 & -.554 & -2.468 & $* 026$ \\
\hline
\end{tabular}

*Significant at one per cent level ** Significant at five per cent level

\subsection{Valuation of stocks}

Next we should identify overpriced and underpriced stocks among the sample group of companies. Actual P/E and their comparison with expected P/E are exhibited in Table 4. The results show that all the stocks from the banking sector were highly undervalued which gives a buy signal for investment. Similarly most of the firms from IT and Pharmaceuticals were also relatively undervalued. But three out of four realty firms and two out of four auto firms were highly overvalued which gives a warning against its holding for the subsequent period. 
Does Value Outperform Growth In A Downturn?

Table 4: Valuation of stocks - Company wise diagnostics

\begin{tabular}{|l|c|c|l|}
\hline \multicolumn{1}{|c|}{ Company } & Actual P/E & Expected P/E & Decision \\
\hline Bank of India & 3.83 & 9.05 & Underpriced \\
SBI & 7.42 & 9.46 & Underpriced \\
Union Bank of India & 4.37 & 11.23 & Underpriced \\
PNB & 4.22 & 9.21 & Underpriced \\
Unitech & 7.70 & 11.48 & Underpriced \\
JP Associates & 11.10 & 4.53 & Overpriced \\
DLF & 18.41 & 11.54 & Overpriced \\
Rel Infra & 10.20 & 7.03 & Overpriced \\
Hero Honda & 16.60 & 13.26 & Overpriced \\
Maruti & 18.51 & 17.15 & Overpriced \\
Mahindra \& Mahindra & 12.42 & 13.64 & Underpriced \\
Tata motors & 9.31 & 14.73 & Underpriced \\
Cipla & 22.11 & 14.75 & Overpriced \\
Lupin & 13.63 & 16.22 & Underpriced \\
Sun pharma & 18.12 & 15.05 & Overpriced \\
Dr. Reddy's & 14.54 & 15.22 & Underpriced \\
TCS & 11.22 & 11.89 & Underpriced \\
Wipro & 12.11 & 12.66 & Underpriced \\
Infosys Technologies & 13.01 & 11.99 & Overpriced \\
HCL Technologies & 6.92 & 8.12 & Underpriced \\
\hline
\end{tabular}

4.5. Outcome of value strategies in subsequent period

Is this kind of security valuation strategy of fundamentalists really helping the investors to produce better returns during the days of crisis? For answering this question the study took an assumption that an investor should have purchased the stocks specified in the sample on the first day of the financial year 2009-2010 and has to hold it till last trading day of the calendar year. By taking the difference in the market values of these stocks on these two dates the study compute the return that he would have made from it. Table 5 summarizes the possible return to investors who would have acted in the way mentioned in the assumption taken.

Table 5: Relative performance of stocks in 2009-10

\begin{tabular}{|l|c|c|c|c|}
\hline \multicolumn{1}{|c|}{ Company } & $\begin{array}{c}\text { Price on } \\
\mathbf{1 / 0 4 / 2 0 0 9}\end{array}$ & $\begin{array}{c}\text { Price on } \\
\mathbf{3 1 / 1 2 / 2 0 0 9}\end{array}$ & Return (\%) & Rank \\
\hline Bank of India & 220.30 & 384.85 & $74.69^{*}$ & 17 \\
\hline SBI & 1077.45 & 2269 & $110.59^{*}$ & 11 \\
\hline Union Bank of India & 147.25 & 264.15 & $79.39^{*}$ & 16 \\
\hline PNB & 405.75 & 906.20 & $123.34^{*}$ & 8 \\
\hline Unitech & 37.35 & 82.30 & $120.35^{*}$ & 10 \\
\hline Jp Associates & 85.40 & $146.85\left(\mathbf{2 2 0 . 2 7 ^ { \# }}\right)$ & 157.92 & 6 \\
\hline DLF & 177.10 & 361.20 & 103.95 & 13 \\
\hline Relinfra & 550.00 & 1146.75 & 108.50 & 12 \\
\hline Herohonda & 1039.75 & 1717.70 & 65.20 & 18 \\
\hline Maruti & 792.50 & 1560.10 & 96.86 & 14 \\
\hline M\&M & 394.95 & 1080.85 & $173.67^{*}$ & 4 \\
\hline Tata motors & 180.00 & 791.55 & $339.75^{*}$ & 1 \\
\hline Cipla & 218.85 & 335.05 & 53.10 & 19 \\
\hline Lupin & 663.20 & 1468.80 & $121.47^{*}$ & 9 \\
\hline Sun pharma & 1065.45 & 1508.80 & 41.61 & 20 \\
\hline Dr. reddy & 482.00 & 1146.60 & $137.88^{*}$ & 7 \\
\hline TCS & 544.50 & $750.25\left(\mathbf{1 5 0 0 . 5 0} \mathbf{p}^{\#}\right)$ & $175.58^{*}$ & 3 \\
\hline Wipro & 252.40 & 681.15 & $169.87^{*}$ & 5 \\
\hline
\end{tabular}


Does Value Outperform Growth In A Downturn?

\begin{tabular}{|l|c|c|c|c|}
\hline Infosys Technologies & 1373.75 & 2601.10 & 89.34 & 15 \\
\hline HCL Technologies & 100.75 & 371.30 & $268.54^{*}$ & 2 \\
\hline
\end{tabular}

Price given in parenthesis indicates market prices of stocks adjusted for bonus issue. JP associates declared bonus in the ratio of 1:2 and TCS in the ratio of 1:1 in 2009-2010. *Stocks undervalued during the previous year.

All the scrips included in the sample were able to deliver relatively good returns to their investors. To an extent we can attribute this fact to the gradual recovery of the stocks from the shock that global economic recession exerted on Indian financial system and also to the reinstatement of the stable political system of the country. Both of these factors restore confidence in the mind of the investors and they rush to purchase the stocks which made a surge in their market value. But when we closely look in to their growth in value during this period we can see that the growth rate was remarkably high in case of stocks which were undervalued by the same market in 2008-09. Of the ten scrips which occupied foremost positions in terms of growth in value among the sample, nine were came from undervalued group. All these stocks were able to produce a return in a range of 120 percent to 340 percent approximately. Out of the eight overvalued stocks of 2008-09, five were able to generate return of less than 100 percent, of which three could give only return at a rate which is even less than one fifth of the return generated by the best scrip among the group.

\section{Conclusion}

For many years academics and practitioners have been pondering the 'value versus growth' issue. P/E ratio, a valuable analytic device most widely used by analysts, and is the key variable in both value and growth strategies. But its use as value strategy is of prime tool to investors in evaluating stock prices from long term perspectives and is particularly helpful in the difficult analysis of shocking economic days. The empirical findings of this study unfold this fact in Indian context. While employing this strategy, more thrust should be given to the earnings growth and market sensitivity components of the scrip under analysis. Since the benchmark $\mathrm{P} / \mathrm{E}$ ratio estimated in the study under a cross sectional regression framework, accuracy of the data used and more than that the stocks understudy all are worth to assess the robustness of its results. Otherwise there is nothing trifling on an apposite benchmark P/E, or determining whether the difference between a given P/E and its appropriate benchmark is due to fundamentals or mispricing.

\section{References}

[1] S. Harikumar. T.G. Saji and C. M. Kasim. Financia market investments during the period of global recession. in P. Arunachalam (Ed.). Impact of Global Financial Crisis on Indian Economy.1 (New Delhi: Global Research Publications. 2010) 588-592.

[2] Financial Express. February 19. Dhaka. 2010.

[3] S. L. Margosh. Price/Earnings Ratio in Financial Analysis: Its Use and Abuse. Financial Analysts Journal. 16(6). 1960. 125-130.

[4] G. Benjamin. and D. L. Dodd. Security Analysis (New York .McGraw Hill.1934)

[5] N. Molodovsky. A Theory of Price-Earnings Ratios. Financial Analysts Journal, November.1953. 65-80.

S. Basu. Investment Performance of Common Stocks in relation their price earnings ratios: A test of the Efficient Market Hypothesis. The Journal Finance. June. 1977. 663-681.

Capaul. I. Rowley. and W. Sharpe. International Value and Growth Stock Returns. Financial Analysts Journal. January/February.1993. 27-36.

[6] J. Lakonishik. A. Shleifer. and R.Vishny. Contrarian Investment, extrapolation, and risk. Journal of Finance. 49. 1994.1541-78.

[7] N.F. Chen. and F. Zhang, F. Risk and return of value stocks. Journal of Business.71. 1998. 501-35.

[8] S. Bauman. M. Conover. and R. Miller. Growth versus Value and Large Cap versus Small Cap Stocks in International Stocks. Financial Analysts Journal, March/April, 1998. 75-89.

[9] S. Estrada. S. Adjusting P/E ratios by growth and risk: the PERG ratio. International Journal of Managerial Finance. 1(3). 2005. 187-203.

[10] J.Y.Campbell. and R.J. Shiller. Valuation Ratios and the Long-Run Stock Market Outlook, Journal of Portfolio Management. 24(2).1998.11-26

[11] S. H. Penman and X.Zhang. Modeling Sustainable Earnings and P/E Ratios with Financial Statement Analysis. Working paper. Columbia Business School. December, 2006.

[12] W. Beaver.and D.Morse. What Determines Price-Earnings Ratios. Financial Analysts Journal. 34. 1978. 65-76.

[13] D.Dreman and M.A.Berry. Analyst Forecast Errors and Their Implications for Security Analysis. Financial Analysts Journal. 51(3). 1995. 30-31.

[14] M. Vorek. Does High Price Earnings Ratio Predict Future Falls of Stock Price? http://www.icabr.com/fullpapers/Vorek\%20Mari\%E1n.pdf, accessed 25/09/2012

[15] M.J. Gordon.Optimum Investment and financing Policy. Journal of Finance. May. 1963.264-272.

[16] J.E. Murphy. and H.W. Stevenson. Price/Earnings Ratios and Future Growth of Earnings and Dividends. Financial Analysts Journal, 23, 1967. 111-114.

[17] B.G.Malkiel and J.G. Cragg. (1970). Expectations and the Structure of Share Prices. American Economic Review. September.1970.601-17.

[18] V.L. Bernard. and J.K.Thomas. Post Earnings Announcement Drift: Delayed Price Response or Risk Premium. Journal of Accounting Research. 27. 1990. 1-36.

[19] A.D. Clare. and S.H, Thomas. Overreaction Hypothesis and UK Stock Market. Journal of Business Finance and Accounting. 22(7). 1995. 961-973. 